\title{
Development of cost-effective real-time PCR test: to detect a wide range of HBV DNA concentrations in the western amazon region of Brazil
}

\author{
Alcione de Oliveira dos Santos ${ }^{1,2,3^{*}}$, Luan Felipo Botelho Souza ${ }^{1,2,3}$, Lourdes Maria Borzacov², \\ Juan Miguel Villalobos-Salcedo ${ }^{1,2,3}$ and Deusilene Souza Vieira ${ }^{1,2,3}$
}

\begin{abstract}
Background: Currently there is a significant risk of infection with hepatitis B virus (HBV) during blood transfusion in high epidemic area. This is due to the pre-seroconversion window period, immunovariant viral strains and the presence of occult HBV infection (OBI). The aim of this study was to develop an in-house real-time PCR-based method, which was both ultra-sensitive and efficient offering an alternative method for nucleic acid testing (NAT).

Methods: A precore fragment with $109 \mathrm{bp}$ was cloned and serial diluted to standard curve construction. The calibration of the HBV - DNA values was performed against OptiQuant ${ }^{\circledR}$ HBV-DNA Quantification Panel, Acrometrix Europe B.V.).

Results: From our in-house plasmid we prepared serial dilutions ranging from $2 \times 10^{3}-2 \times 10^{9}$ copies $/ \mathrm{ml}$. The threshold was adjusted automatically during analysis and the data collected were analyzed by linear regression $\left(r^{2}=0.99\right)$. The limit of detection for the assay with pHBVRO standards was $2000 / \mathrm{ml}$ in a total reaction volume of $30 \mu \mathrm{l}$. We found a strong correlation between the two methods $\left(r^{2}=0.9965\right.$ and $\left.p<0.0001\right)$. The regression line give us the following equation: $\log 10(\mathrm{IU} / \mathrm{mL})=0.9038 \mathrm{Log} 10($ copies $/ \mathrm{mL})-1.0643$, suggesting that $1 \mathrm{IU} / \mathrm{mL}=15$ copies/mL.

Conclusions: Therefore, we can affirm that the GHBVRO PCR can detect HBV DNA in individuals with hepatitis B at any stage of the disease showing high capacity for NAT screening in hepatitis b donors. This results of sensitivity could provide an advance for automation in blood banks and increasing safety of patients who receive blood transfusions.
\end{abstract}

\section{Introduction}

The hepatitis B virus (HBV) is one of the most common human pathogens and can cause hepatitis and aggressive and advanced liver disease, including cirrhosis and hepatocellular carcinoma [1]. Despite the availability of a vaccine, the implementation of preventive measures and serological screening in blood banks remains a major public health problem worldwide [2]. HBV can be transmitted perinatally, percutaneously, sexually or by horizontal transmission, especially among children, presumably through open cuts or sores [3].

\footnotetext{
* Correspondence: alcione.m@hotmail.com

'Fundação Oswaldo Cruz, Rondônia-FIOCRUZ, Porto Velho, Rondonia, Brazil ${ }^{2}$ Centro de Pesquisa em Medicina Tropical de Rondônia-CEPEM, Porto Velho, Rondonia, Brazil

Full list of author information is available at the end of the article
}

Early detection of HBV surface antigen (HBsAg) significantly reduces the risk of infection through blood transfusions [4]. However, there are two situations in the course of infection where this early detection is currently ineffective: First, during the acute phase of infection, there is a window period where HBsAg may be undetectable in serum [5]. In another situation, occult infection which is defined as the presence of HBV DNA in the liver (with or without detectable serum HBV DNA) may be present during the persistent of infection in subjects who test negative for hepatitis B surface antigen ( $\mathrm{HBsAg})$. These subjects often have very low viral load $(<200 \mathrm{UI} / \mathrm{ml})$ [6]. Reducing the risk of transmission in these situations will require increased sensitivity the detection of HBV surface antigen (HBsAg), screening for antibodies to HBV core antigen (anti-HBc), and continued testing and implementation of NATs $[7,8]$.

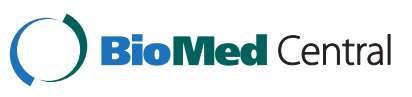


Real-time polymerase chain reaction (qRT-PCR) has enabled the development of improved diagnostic tests offering greater speed while maintaining excellent levels of sensitivity and specificity [9-11]. qRT-PCRbased detection methods have been developed for the diagnosis of $\mathrm{HBV}$ and other pathologies in clinical laboratories [12-14].

To successfully monitor viral load, it is important to diagnose viral replication, establish the prognosis of liver disease, to assess the risk of disease progression, to identify patients who need antiviral therapy and to monitor the virologic response to treatment. Currently there are several types of detection and quantitation assays in use, with varying levels of success $[15,16]$. The aim of this study was to develop an in-house real-time PCR-based method, which was both ultra-sensitive and effective, offering a new NAT alternative.

\section{Materials and methods Clinical samples}

This study included 134 patients with chronic HBV infection who were treated at the Viral Hepatitis Clinic Specialized Center of Research in Tropical Medicine in Rondonia (CEPEM). A control group of 30 donors, who all tested negative por ELISA for human immunodeficiency virus (HIV) 1 and 2, HBsAg, anti-HBc and anti$\mathrm{HCV}$, and who attended the blood bank of the State of Rondonia (FHEMERON) was included in the study. We also included 10 and 26 serum samples from individuals with chronic $\mathrm{HCV}$ and co-infection with $\mathrm{HBV} / \mathrm{HDV}$ respectively.

\section{Ethical consent}

This study was approved by the Brazilian Institutional Ethics Committee of the Centro de Pesquisa em Medicina Tropical (CEPEM), with process number 107/10. Written, informed consent was obtained from each patient for the publication of this manuscript and any accompanying images.

\section{DNA extraction}

Viral DNA extraction was performed using the QIAamp DNA Mini Kit (Qiagen, Hilden, Germany) and $200 \mu \mathrm{l}$ of serum according to the manufacturer's instructions. Three samples with viral load known were tested: first with high viral load and the others medium and low viral load. After this were diluted with final volume $200 \mathrm{ul}, 100 \mathrm{ul}$ and 50 ul. Besides, HBV DNA was extracted from 22 samples of individuals with same profile serological: total isolated anti-HBc. These samples were diluted in $50 \mathrm{uL}$ and $200 \mathrm{uL}$ to optimize the final volume of extraction for samples with low viral load. Subsequently the samples were submitted to reaction for sensitivity analysis. Precipitated DNA was resuspended in elution buffer and stored at $-20^{\circ} \mathrm{C}$ until further use. To avoid false-positive results, we followed strict procedures for nucleic acid amplification [17].

\section{In-house testing}

Primer concentrations were optimized using a concentration gradient ranging from 100-900 nM and SYBR ${ }^{\circ}$ Universal PCR Master Mix (Applied Biosystems, Foster City, CA, USA). TaqMan ${ }^{\circledR}$ probe concentrations were similarly optimized using a concentration gradient ranging from 50-300 $\mathrm{nM}$.

\section{Ultra-sensitive real-time PCR}

The assay was performed on an ABI 7500 platform (Applied Biosystems) with $30 \mu \mathrm{l}$ reaction volumes containing $15 \mu \mathrm{l}$ TaqMan ${ }^{\odot}$ Universal Master Mix (Applied Biosystems), $3 \mu \mathrm{l}$ HBVRO1 forward primer (5' -AGGAGGCTGTAGGCATAAATTGG 3'), $3 \mu \mathrm{l}$ reverse primer (5'-GCACAGCTTGG AGGCTTG-3'), $0.6 \mu \mathrm{l}$ probe (5'-FAM TCACCTCTGCC TAATC-3' - MGB, $6 \mu \mathrm{l}$ extracted DNA and $2.4 \mu \mathrm{l}$ of water.

\section{Construction of the standard curve}

To construct the standard curve, we initially used conventional PCR with amplification of a $109 \mathrm{bp}$ fragment in the pre-core region according Kavita 2006 adapted, selecting five samples with known viral load. Approximately $50 \mathrm{ng}$ of DNA was used per reaction with a final volume of $50 \mu$ l. Amplification was performed on an ABI Prism 7500 Veriti (Applied Biosystems) with an initial denaturation temperature of $94^{\circ} \mathrm{C}$ for $5 \mathrm{~min}$, followed by 40 cycles of $94^{\circ} \mathrm{C}$ for $1 \mathrm{~min}, 58^{\circ} \mathrm{C}$ for $45 \mathrm{sec}, 72^{\circ} \mathrm{C}$ for $1 \mathrm{~min}$ and a final extension of $10 \mathrm{~min}$ at $72^{\circ} \mathrm{C}$. The selected fragment was purified, ligated to the $\mathrm{p}-\mathrm{GEM}-\mathrm{T}$ Easy ${ }^{\oplus}$ vector (Promega, New York, USA), cloned into a prokaryotic system and subsequent linearization with PstI (Invitrogen ${ }^{\mathrm{TM}}$ Life Technologies, Carlsbad, CA, USA). Absolute quantitation was used to determine the exact number of DNA molecules for estimating viral load.

Inter- and intra-assay variation and reproducibility of realtime PCR

To determine intra-experimental variation, we tested the reproducibility of six $\mathrm{HBV}$-positive sera with different viral loads, in duplicate, in the same reaction setup. The same set of samples was used in three experiments performed on different days, to estimate inter-experimental variation in the estimation of viral load. Reproducibility was estimated by calculating the coefficient of variation $(\mathrm{CV})$, which is calculated as the ratio of the standard deviation and the mean of the replicates.

\section{HBV DNA quantification}

Calibration curves for HBV DNA were constructed using the OptiQuant ${ }^{\odot}$ HBV-DNA Quantification Panel, 


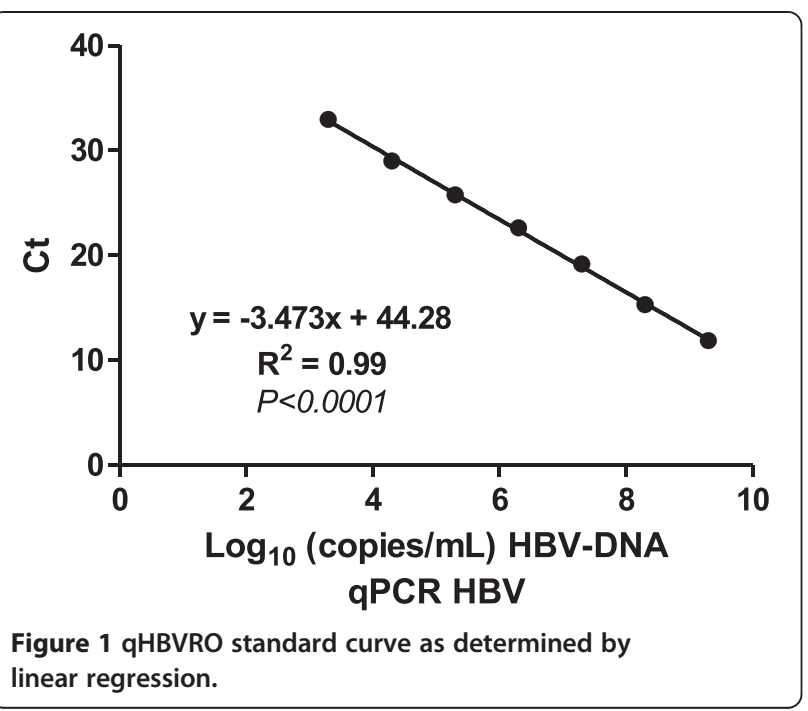

(AcroMetrix Europe BV). Specifically, a serial dilution was prepared from the standards included in the kit, ranging from $2 \times 10^{2}-2 \times 10^{6} \mathrm{IU} / \mathrm{ml}$. For our in-house plasmid, pHBVRO, a serial dilution was prepared with a range $2 \times$ $10^{3}-2 \times 10^{9}$ copies $/ \mathrm{ml}$. The concentration was measured spectrophotometrically both by using a NanoDrop ${ }^{\circ}$ ND1000 (Thermo Scientific NanoDrop Products, Wilmington, Delaware), and the measurements were recorded in units of nanograms per microliter, which was converted into copies per microliter by using the following equation: ( $\left[\mathrm{x} \mathrm{ng} / \mu \mathrm{L} \times 10^{-9}\right] /$ [p-GEM-T Easy ${ }^{\circ}$ vector and $109 \mathrm{HBV}$ DNAbps $\times 660]) \times 6.022 \mathrm{e}^{23}=\mathrm{y}$ copies $/ \mu \mathrm{L}$. Using linear regression a standard curve was constructed, which was used to convert copies/ml to standard international units $(\mathrm{IU} / \mathrm{ml})$.

\section{Quantification panel}

To compare the performance of our in-house method (qHBVRO) with that of the commercial kit, OptiQuant ${ }^{\circ}$ HBV-DNA Quantification Panel (AcroMetrix ${ }^{\circ}$ Europe BV), we tested 100 serum samples collected from patients chronically infected with HBV.

\section{Statistical analysis}

The correlation between the AcroMetrix test kit and the qHBVRO assay was calculated using GraphPad 5.0 (GraphPad software) and a two-tailed Pearson's correlation test with a confidence interval of $95 \%$. The units for measuring viral load (copies $/ \mathrm{ml}$ and $\mathrm{IU} / \mathrm{ml}$ ) were transformed to $\log$ base 10 .

\section{Analytical specificity}

We tested 30 samples from blood donors, 10 serum samples from mono-infected HCV patients, 28 samples from patients co-infected with HBV/HDV and 15 samples that were judged indeterminate for HBV surface antigen by the Serology Laboratory of Viral Hepatitis Clinic - IPEPATRO. All samples were submitted to $\mathrm{AHBV}$ PCR to determine viral load.

\section{Analytical sensitivity}

We selected 15 sera, which were considered indeterminate for HBsAg by ELISA when tested in duplicate and which had absorbance values within the gray zone, or \pm $10 \%$ cut-off confidence interval. These samples were subjected to three separate assays, with each sample performed in duplicate to evaluate the performance of our assay in detecting uncertain samples.

\section{Results}

\section{Analytical sensitivity and efficiency}

From our in-house plasmid we prepared serial dilutions ranging from $2 \times 10^{3}-2 \times 10^{9}$ copies $/ \mathrm{ml}$. The concentration of primers used was $300 \mathrm{nM}$, for both primers, and $100 \mathrm{nM}$ for the probe. The threshold was adjusted automatically during analysis and the data collected were analyzed by linear regression $\left(r^{2}=0.99\right)$, Figure 1 . The limit of detection for the assay with pHBVRO standards was $2000 / \mathrm{ml}$ in a total reaction volume of $30 \mu \mathrm{l}$. Two positive samples with known viral load were used as internal controls. HBV DNA extraction was patterned on elution of $200 \mu \mathrm{l}$ because there was no significant variation in sensitivity of method in different volumes of patients with intermediate and high viral load. But the 22 samples of patients with serological profile "anti-HBc

Table 1 Intra-experimental variation in the qHBVRO assay for serum samples

\begin{tabular}{|c|c|c|c|c|c|c|}
\hline \multicolumn{7}{|c|}{ qHBV RO - intra assay } \\
\hline Sample & 1st run $(\mathrm{IU} / \mathrm{mL})$ & 2nd run $(\mathrm{IU} / \mathrm{mL})$ & 3th run $(\mathrm{IU} / \mathrm{mL})$ & Avarage inter assay & SD & $\mathrm{CV}$ \\
\hline 1 & $4.6 \times 10^{6}$ & $4.6 \times 10^{6}$ & $4.6 \times 10^{6}$ & $4.6 \times 10^{6}$ & $0.027 \times 10^{6}$ & $\overline{0,01}$ \\
\hline 2 & $2.8 \times 10^{4}$ & $2,7 \times 10^{4}$ & $2.7 \times 10^{4}$ & $2.7 \times 10^{4}$ & $0.025 \times 10^{4}$ & 0,01 \\
\hline 3 & $5.0 \times 10^{2}$ & $4.3 \times 10^{2}$ & $4.6 \times 10^{2}$ & $4.6 \times 10^{2}$ & $0.36 \times 10^{2}$ & 0,08 \\
\hline 4 & $3.2 \times 10^{2}$ & $2.9 \times 10^{2}$ & $2.7 \times 10^{2}$ & $3.0 \times 10^{2}$ & $0.26 \times 10^{2}$ & 0,09 \\
\hline 5 & $3.3 \times 10^{5}$ & $3.1 \times 10^{5}$ & $3.0 \times 10^{5}$ & $3.2 \times 10^{5}$ & $0.16 \times 10^{5}$ & 0,05 \\
\hline 6 & $4.8 \times 10^{4}$ & $4.0 \times 10^{4}$ & $4.3 \times 10^{4}$ & $4.4 \times 10^{4}$ & $0.38 \times 10^{4}$ & 0,09 \\
\hline
\end{tabular}


Table 2 Inter-experimental variation in the qHBVRO assay for serum samples

\begin{tabular}{|c|c|c|c|c|c|c|}
\hline \multicolumn{7}{|c|}{ qHBV RO - inter assay } \\
\hline Sample & 1 st run $(\mathrm{IU} / \mathrm{mL})$ & 2nd run (IU/mL) & 3th run $(\mathrm{IU} / \mathrm{mL})$ & Avarage inter assay & SD & $\mathrm{CV}$ \\
\hline 1 & $4.6 \times 10^{6}$ & $5.0 \times 10^{6}$ & $4.6 \times 10^{6}$ & $4.7 \times 10^{6}$ & $0.02 \times 10^{6}$ & 0,05 \\
\hline 2 & $2.7 \times 10^{4}$ & $3.4 \times 10^{4}$ & $27 \times 10^{4}$ & $2.9 \times 10^{4}$ & $0.004 \times 10^{4}$ & 0,14 \\
\hline 3 & $4.3 \times 10^{2}$ & $4.6 \times 10^{2}$ & $4.0 \times 10^{2}$ & $4.3 \times 10^{2}$ & $0.3 \times 10^{2}$ & 0,07 \\
\hline 4 & $3.2 \times 10^{2}$ & $2.7 \times 10^{2}$ & $3.0 \times 10^{2}$ & $3.0 \times 10^{2}$ & $0.2 \times 10^{2}$ & 0,08 \\
\hline 5 & $3.3 \times 10^{5}$ & $3.0 \times 10^{5}$ & $2.8 \times 10^{5}$ & $3.0 \times 10^{5}$ & $0.2 \times 10^{5}$ & 0,08 \\
\hline 6 & $5.0 \times 10^{4}$ & $4.9 \times 10^{4}$ & $4.0 \times 10^{4}$ & $4.6 \times 10^{4}$ & $0.5 \times 10^{4}$ & 0,11 \\
\hline
\end{tabular}

total isolated" eluted in 50 and $200 \mathrm{uL}, 15$ samples were negative on both elution, 5 samples were positive only in elution of $50 \mathrm{uL}$ within which 2 samples were positive in both elution.

Inter- and intra-assay variation and reproducibility of realtime PCR

The six HVB-DNA positive sera tested showed no statistical differences between repeats. The coefficient of variation was similar in both high and low viral load samples (0.01-0.16\%), indicating the same efficiency of amplification for varying viral loads. There was no statistical difference in intra-and inter-assay variation $(\mathrm{CV})$, which confirmed the reproducibility of the assay (Tables 1 and 2).

\section{Validation of the qHBVRO method}

Using linear regression, we found a strong correlation between the qHBVRO assay and the AcroMetrix ${ }^{\circledast} \mathrm{HBV}$ DNA kit $\left(\mathrm{r}^{2}=0.998\right.$ and $\left.\mathrm{p}<0.0001\right)$ as shown in Figure 2. Viral load values between the AcroMetrix ${ }^{\oplus}$ HBV-DNA and the qHBVRO assay were compared for 134 patients by Pearson's correlation. We found a strong correlation between the two methods $\left(r^{2}=0.9965\right.$ and $\left.p<0.0001\right)$. The regression line give us the following equation:

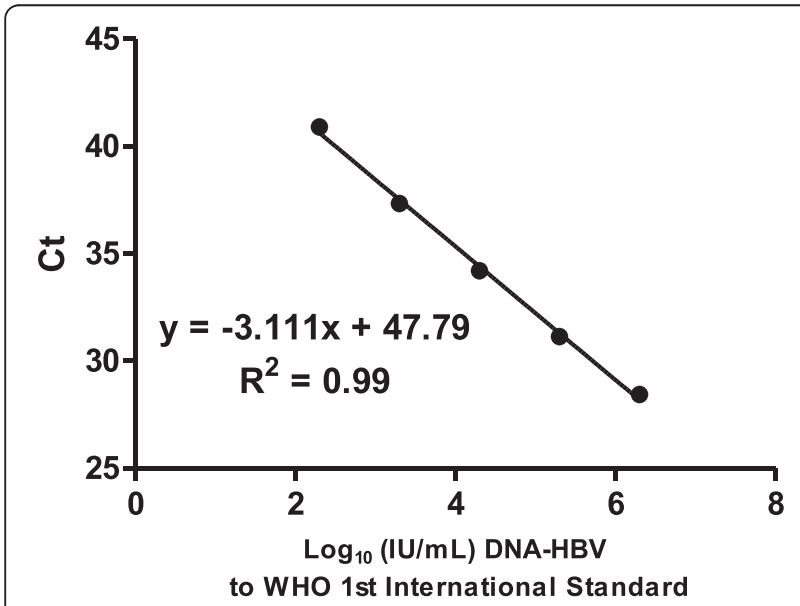

Figure 2 WHO 1st International Standard (HBV ${ }^{\circledR}$ kit Acrometrix DNA) as determined by linear regression. $\log 10(\mathrm{IU} / \mathrm{mL})=0.9038 \log 10($ copies $/ \mathrm{mL})-1.0643$, suggesting that $1 \mathrm{IU} / \mathrm{mL}=15$ copies $/ \mathrm{mL}$ (Figure 3 ).

\section{Analytical specificity and detection performance of} indeterminate for ELISA samples and anti-HBc isolated samples

Of the 15 indeterminate for ELISA samples tested, six were positive for HBV DNA by both methods (Table 3). All samples that were classified as negative by ELISA were confirmed as such as shown. Of the 22 samples isolated anti-HBc eluted in $50 \mathrm{uL}, 5$ were positive (Figure 4).

\section{Discussion}

Currently, there is a significant risk of infection with hepatitis $\mathrm{B}$ virus (HBV) during blood transfusions. This is due to the pre-seroconversion window period, immunovariant viral strains and the presence of occult $\mathrm{HBV}$ infection (OBI) $[8,18,19]$. Combined detection of HBsAg and anti$\mathrm{HBc}$ constitutes an important strategy in donor screening which excludes the vast majority of OBIs [20-22]. However, in many countries, especially in areas of low HBV prevalence $(<3 \%)$ these strategies are inefficient especially during the pre-seroconversion window period. However, in countries with high prevalence of positivity for

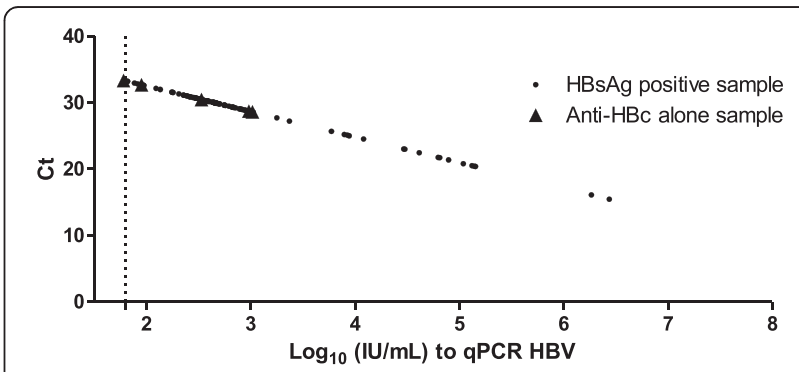

Figure 3 Analytical sensitivity of qPCR HBV demonstrated with 97 samples: 91 samples positive for HBsAg and 6 samples total anti-HBc isolated. These 6 samples were DNA-HBV positive detected within 50 clinical samples tested in patients with profile total anti-HBC isolated. The dashed line is the limit of analytical detection of qPCR HBV. 
Table 3 Data summary for indeterminate samples

\begin{tabular}{cccccccccc}
\hline & 1st run $\left(\mathbf{C t}^{*}\right)$ & 2nd run $\left(\mathbf{C t}^{*}\right)$ & 3th run $\left(\mathbf{C t}^{*}\right)$ & Mean & SD & CV & Log $_{\text {10 }}$ IU/ml & DO* & Cut-off \\
\hline 1 & 37.31 & 37.56 & 37.74 & 37.54 & 0.21595 & $1 \%$ & 0.69 & 0.086 & 0.062 \\
2 & 38.90 & 38.98 & 39.1 & 38.99 & 0.10066 & $0 \%$ & 0.31 & 0.075 & 0.079 \\
3 & 38.69 & 38.83 & 38.95 & 38.82 & 0.13013 & $0 \%$ & 0.35 & 0.070 & 0.063 \\
4 & 37.47 & 37.54 & 37.87 & 37.63 & 0.21362 & $1 \%$ & 0.66 & 0.062 & 0.065 \\
5 & 39.05 & 39.1 & 39.45 & 39.20 & 0.21794 & $1 \%$ & 0.25 & 0.060 & 0.068 \\
6 & 38.94 & 39.03 & 39.26 & 39.08 & 0.16503 & $0 \%$ & 0.28 & 0.069 & 0.068 \\
\hline
\end{tabular}

DO*: Optical Density by spectrophotometry (ELISA).

$\mathrm{Ct}^{*}$ : Amplification cycle in the assay qHBVRO.

anti-HBc, using this marker could involve both the exclusion of several potential donors leading to a decrease of blood products in various regions - such as the failure to block potential donors with OBI - keeping present the risk of post-transfusion HBV $[18,23]$. The qHBVRO test presents an excellent alternative to HBV detection and quantification because it allows significant reduction in the risk of transmission during the window period as well as improved detection of occult HBV.

In this study we developed a qRT-PCR assay for the identification and quantification of HBV DNA with an efficiency of $94.06 \%$ and good correlation with the currently used commercial test: WHO 1st International Standard $\left(\mathrm{HBV}^{\bullet}\right.$ kit Acrometrix DNA), $\mathrm{r}=0.998, \mathrm{p}<0.0001$. The qHBVRO PCR test was 100 fold more sensitive, allowing detection of up to two thousand copies per $\mathrm{ml}$ of serum in $\mathrm{HBV}$-infected individuals. Our method also proved to be more sensitive than other in-house qRT-PCRs [24-26], and could detect occult hepatitis B infections as well as cases which were inconclusive by ELISA, using only $6 \mu \mathrm{l}$ of DNA extracted from $200 \mu \mathrm{l}$ of serum in final reaction volume of $30 \mu \mathrm{l}$ for qHBVRO. However, was observed that in cases of samples with low viral load is important to consider a smaller volume in the elution of DNA. It is the case of 22 samples tested from individuals with isolated anti-HBc where 5 were positive in $50 \mathrm{uL}$ elution and only 2 were positive on PCR qHBV. These results reinforce the importance that in case of occult infection or immunological

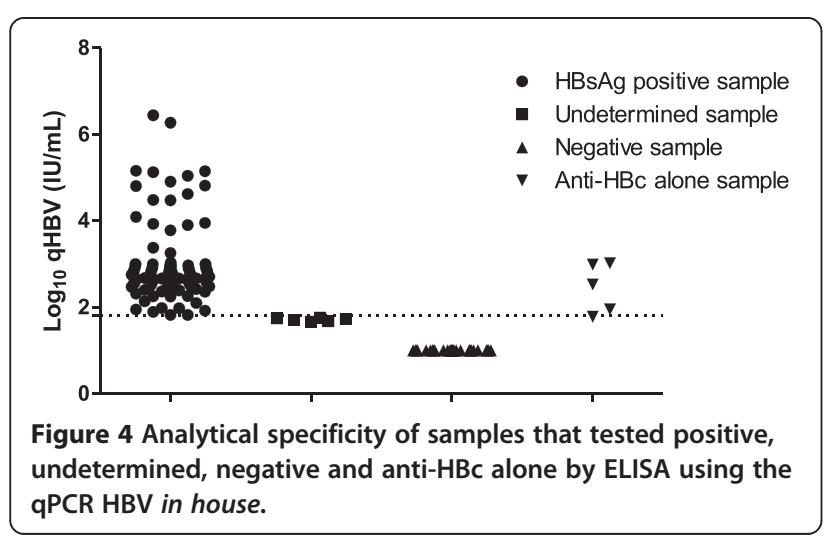

window period, the concentration of DNA is an important factor to consider.

The high analytical specificity of the test, using samples from individuals that tested positive, negative and indeterminate for HBsAg by ELISA demonstrates that qHBVRO PCR can detect HBV DNA in individuals with hepatitis B at any stage of the disease, qualifying it as an important alternative NAT. The qHBVRO assay is highly reproducible, with low intra- and inter-experimental variation of between $0-1 \%(\mathrm{CV})$, whereas other in-house tests, which are considered to have good reproducibility, show experimental variation of 4.94-10.59\% [27-31].

Our method proved to be efficient, sensitive, specific and reproducible in the detection of occult HBV, and could therefore be used for nucleic acid testing (NAT) in blood banks to prevent HBV transmission by blood transfusion. The advantages of NAT relating to cost and effectiveness compared with serological diagnostics have been widely debated [28-30]. It has been suggested that NAT offers advantages in many instances including occult infections, in the confirmation of viremia, for screening bloodand organ-donors, discriminating between patients with chronic or acute infection which has been resolved, diagnosis of perinatal infection, solving indeterminate serological results, monitoring patients on antiviral therapy and to identify the virus in immunocompromised individuals [31-33].

\section{Conclusion}

In conclusion, the real-time PCR assay qHBVRO is appropriate for the quantification of HBV DNA in serum samples. This test is reproducible and proved be sensitive detecting samples with low viral load. Therefore, we can affirm that the qHBVRO PCR can detect HBV DNA in individuals with hepatitis $\mathrm{B}$ at any phase of disease showing good NAT screening for hepatitis B. Samples of patients anti-HBc positive isolated were selected and submitted to qHBVRO test to enhancing sensitivity the this results. This developed test may be automated and used in blood banks, increasing safety of patients who receive blood transfusions. 


\section{Competing interests}

The authors declare that they have no financial or competing interest with this article.

\section{Authors' contributions}

AOS participated in the design of the study, drafted the manuscript and in its design and coordination. LFBS participated in the PCR amplification and sequencing process. DSV participated in the design of the study. LMB participated in the elaboration of the manuscript. JMS participated in the design of the study. All authors read and approved the final manuscript.

\section{Acknowledgments}

This work was supported by IPEPATRO, CEPEM, Universidade Federal de Rondônia and Fundação Oswaldo Cruz- Rondônia. Our thanks to Larissa Deadame F Nicolete by collaboration in the statistical analyzes.

\section{Author details}

${ }^{1}$ Fundação Oswaldo Cruz, Rondônia-FIOCRUZ, Porto Velho, Rondonia, Brazil. ${ }^{2}$ Centro de Pesquisa em Medicina Tropical de Rondônia-CEPEM, Porto Velho, Rondonia, Brazil. ${ }^{3}$ Universidade Federal de Rondonia-UNIR, Porto Velho, Rondonia, Brazil.

Received: 3 June 2013 Accepted: 14 January 2014

Published: 28 January 2014

\section{References}

1. Ganem D, Prince AM: "Hepatitis B virus infection-natural history and clinical consequences". N Engl J Med 2004, 350:1118-1129.

2. Kitab B, Essaid EL Feydi A, Afifi R, Trepo C, Benazzouz M, Essamri W, Zoulim F, Chemin I, Alj HS, et al: "Variability in the precore and core promoter regions of HBV strais in Morocco: characterization and impact on liver diasease progression. PLoS One 2012, 7:e42891.

3. Bauer T, Sprinzl M, Protzer U: Immune control of hepatitis B virus. Dig Dis 2011, 29:423-433.

4. Kuhns MC, Kleinman SH, McNamara AL, Rawal B, Glynn S, Busch MP: "Lack of correlation between HBsAg and HBV DNA levels in blood donors who test positive for $\mathrm{HBsAg}$ and anti-HBc: implications for future HBV screening policy". Transfusion 2004, 44:1332-1339.

5. Datta S, Banerjee A, Chandra PK, Chakraborty S, Basu SK, Chakravarty R: "Detection of a premature stop codon in the surface gene of hepatitis B virus from an HBsAg and antiHBc negative blood donor". J Clin Virol 2007, 40:255-258.

6. Raimondo G, Navarra G, Mondello S, Costantino L, Colloredo G, Cucinotta E, Di Vita G, Scisca C, Squadrito G, et al: "Occult hepatitis B virus in liver tissue of individuals without hepatic disease". J Hepatol 2008, 48:743-746.

7. Saldanha J: Validation and standardisation of nucleic acid amplification technology (NAT) assays for the detection of viral contamination of blood and blood products. J Clin Virol 2001, 20:7-13.

8. Candotti D, Allain JP: "Transfusion-transmitted hepatitis B virus infection". J Hepatol 2009, 51:798-809.

9. Foy CA, Parkes HC: "Emerging homogeneous DNA-based technologies in the clinical laboratory". Clin Chem 2001, 47:990-1000.

10. Arya SC, Agarwal N: "Hepatitis B vaccination of health care workers in Saudi Arabia". Am J Infect Control 2005, 33:613-614. author reply 612-613.

11. Gunson RN, Abraham E, Carman WF: "Contamination with PCR detectable virus in a virus isolation quality assurance panel". J Virol Methods 2006, 137:150-151.

12. Pas SD, Fries E, De Man RA, Osterhaus AD, Niesters HG: Development of a quantitative real-time detection assay for hepatitis B virus DNA and comparison with two commercial assays. J Clin Microbiol 2000, 38:2897-2901

13. Weiss MJ: "Beware! Uncle Sam has your DNA: legal fallout from its use and misuse in the U.S". Ethics Inf Technol 2004, 6:55-63.

14. Ronsin C, Pillet A, Bali C, Denoyel GA: "Evaluation of the COBAS AmpliPrep-total nucleic acid isolation-COBAS TaqMan hepatitis $B$ virus (HBV) quantitative test and comparison to the VERSANT HBV DNA 3.0 assay". J Clin Microbiol 2006, 44:1390-1399.

15. Berger A, Preiser W, Doerr HW: "The role of viral load determination for the management of human immunodeficiency virus, hepatitis $B$ virus and hepatitis C virus infection". J Clin Virol 2006, 20:23-30.
16. Mackay IM, Arden KE, Nitsche A: "Real-time PCR in virology". Nucleic Acids Res 2002, 30:1292-1305.

17. Kwok S, Higuchi R: Avoiding false positives with PCR. Nature 1989, 339:237-238.

18. Liu CJ, Kao JH, Chen DS: "Kinetics of hepatitis B virus reactivation after chemotherapy: more questions than answers". Gastroenterology 2006, 131:1656-1657.

19. Panigrahi R, Majumder S, Gooptu M, Biswas A, Datta S, Chandra PK, Banerjee A, Chakrabarti S, Bandopadhyay D, et al: "Occult HBV infection among anti-HBc positive HIV-infected patients in apex referral centre, Eastern India". Ann Hepatol 2012, 11:870-875.

20. Allain JP: "Occult hepatitis B virus infection: implications in transfusion". Vox Sang 2004, 86:83-91

21. Fang CT: "Blood screening for HBV DNA". J Clin Virol 2006, 36(1):30-32.

22. Keyvani H, Agah S, Kabir A, Alavian SM: "Prevalence and risk factors of isolated anti-HBC antibody and occult hepatitis B infection in hemodialysis patients: a nationwide study". Ann Hepatol 2013, 12:213-219.

23. Chakrabarti S, Bandopadhyay D: "Occult HBV infection among anti-HBC positive HIV-infected patients in apex referral centre, Eastern India". Ann Hepatol 2012, 11:870-875.

24. Paraskevis D, Beloukas A, Haida C, Katsoulidou A, Moschidis Z, Hatzitheodorou H, Varaklioti A, Sypsa V, Hatzakis A: Development of a new ultra sensitive real-time PCR assay (ultra sensitive RTQ-PCR) for the quantification of HBV-DNA. Virol J 2010, 7:57.

25. Paraskevis D, Haida C, Tassopoulos N, Raptopoulou M, Tsantoulas D, Papachristou H, Sypsa V, Hatzakis A: Development and assessment of a novel real-time PCR assay for quantitation of HBV DNA. J Virol Methods 2012, 103:201-212

26. Lole KS, Arankalle VA: "Quantitation of hepatitis B virus DNA by real-time PCR using internal amplification control and dual TaqMan MGB probes". J Virol Methods 2006, 135:83-90.

27. Pawlotsky JM, Bastie A, Hezode C, Lonjon I, Darthuy F, Remire J, Dhumeaux D: "Routine detection and quantification of hepatitis B virus DNA in clinical laboratories: performance of three commercial assays". J Virol Methods 2000, 85:11-21.

28. Noborg U, Gusdal A, Pisa EK, Hedrum A, Lindh M: "Automated quantitative analysis of hepatitis B virus DNA by using the Cobas Amplicor HBV monitor test". J Clin Microbiol 1999, 37:2793-2797.

29. Yoshikawa A, Gotanda Y, Itabashi M, Minegishi K, Kanemitsu K, Nishioka K: HBV NAT positive [corrected] blood donors in the early and late stages of HBV infection: analyses of the window period and kinetics of HBV DNA. Vox Sang 2005, 88:77-86.

30. Leung VK, Lee CK, Chau TN, Cheung WI, Lo FH, Lai KB, Lin CK: "A probable case of transfusion-transmitted hepatitis $B$ virus infection in an immunosuppressed recipient caused by an occult HBV-infected donor with negative ID-NAT". Transfus Med 2010, 20:276-277.

31. Tani $Y$, Aso H, Matsukura H, Tadokoro K, Tamori A, Nishiguchi S, Yoshizawa $\mathrm{H}$, Shibata H: Significant background rates of HBV and HCV infections in patients and risks of blood transfusion from donors with low anti-HBC titres or high anti-HBc titres with high anti-HBs titres in Japan: a prospective, individual NAT study of transfusion-transmitted HBV, HCV and HIV infections. Vox Sang 2012, 102:285-293.

32. Chatterjee $K$ : An improved nat assay with enhanced sensitivity for hbv for donor blood screening. J Lab Physicians 2012, 4:127.

33. Liu CJ, Chen DS, Chen PJ: "Epidemiology of HBV infection in Asian blood donors: emphasis on occult HBV infection and the role of NAT. J Clin Virol 2006, 36:33-44.

\section{doi:10.1186/1743-422X-11-16}

Cite this article as: de Oliveira dos Santos et al:: Development of cost-effective real-time PCR test: to detect a wide range of HBV DNA concentrations in the western amazon region of Brazil. Virology Journal 2014 11:16. 